\title{
PEMANFAATAN POTENSI LIMBAH KULIT BAWANG MERAH (Allium Cepa. L) SEBAGAI SEDIAAN GEL HAND SANITIZER
}

\author{
Yusnita Usman \\ STIKES Nani Hasanuddin Makassar \\ Email korespondensi : yusnitausman@yahoo.com
}

\begin{abstract}
ABSTRAK
Salah satu penyebab meningkatnya masalah kesehatan adalah ditemukannya mikroorganisme pada tangan. Gel hand sanitizer sebagai jalan keluar untuk menjaga kesehatan dan kebersihan tangan karena lebih praktis dan mudah dibawa. Tujuan dari penelitian ini adalah untuk membuat formulasi sediaan gel yang stabil secara fisik dan memiliki aktivitas penghambatan terhadap bakteri Staphylococcus aureus. Dalam penelitian ini dibuat 3 formulasi sediaan dengan perbandingan hidroksi etil selilulose $0.5 \%, 1 \%$ dan $2 \%$ kemudian dilakukan pengujian stabilitas fisik meliputi organoleptik, homogenitas, $\mathrm{pH}$ dan daya sebar sebelum dan setelah penyimpanan dipercepat kemudian dilakukan pengujian aktivitas antimikroba dengan metode sumuran. Pengamatan organoleptik menunjukkan tidak adanya perubahan warna, aroma/bau dan tekstur. Hasil pengujian homogenitas pada formula dengan konsentrasi basis $0,5 \%$ ini tidak homogen, sedangkan formula dengan konsentrasi basis $1 \%$ dan $2 \%$ homogen. Hasil pengujian $\mathrm{pH}$ menunjukkan bahwa sediaan gel hand sanitizer tidak mengalami perubahan $\mathrm{pH}$. Pada pengujian daya sebar gel dengan konsentrasi basis hidroksietil selulosa $1 \%$ memiliki nilai daya sebar tertinggi. Namun, hasil statistik uji $\mathrm{T}$ berpasangan statistik menunjukkan bahwa daya sebar sebelum dan setelah penyimpanan dipercepat berbeda signifikan 0.043 ( $\mathrm{p}<0.05$ ), akan tetapi hasilnya masih sesuai dengan rentang nilai spesifikasi daya sebar untuk sediaan semipadat yang baik. Hasil Uji MIC (Minimum Inhibitory Concentration) menunjukkan Gel ekstrak etanol kulit bawang merah F1, F2 dan F3 termasuk dalam sediaan yang memberikan daya hambat kuat yaitu gel ekstrak etanol kulit bawang merah F1 daya hambat sebesar 16mm, F2 dan F3 memilki daya hambat yang sama sebesar 14,33. Jadi dapat disimpulkan bahwa formulasi F2 (hidroksi etil selulosa $1 \%$ ) memiliki stabilitas fisik yang yang terbaik namun formulasi $\mathrm{F} 1$ (hidroksi etil selulosa $0,5 \%$ ) paling efektif mrnghambat bakteri Staphylococcus aureus.
\end{abstract}

Kata kunci : Kulit Bawang Merah, Hidroksi Etil Selulosa, Stabilitas Fisik, Gel. 


\title{
UTILIZATION OF RED ONION (Allium Cepa. L) WASTE AS HANDSANITIZER GEL
}

\begin{abstract}
The increased health problems caused by microorganisms at the hands, hand sanitizer gel as the way out to maintained health and hand hygiene because it is more practical and easy to carry. The purpose of this study was to make formulations of gel with physically stable and had inhibitory activity against the Staphylococcus aureus bacteria. In this study three formulations were made with a ratio of Hydroxy ethyl selilulose $0.5 \%(F 1), 1 \%(F 2)$ and 2\% (F3) then physical stability testing included organoleptic, homogeneity, $\mathrm{pH}$ and dispersion before and after accelerated storage, then antimicrobial activity by sump method. Organoleptic test showed there is no color, smell and texture changes. The results of the homogenety test, formula with concentration of Hydroxy ethyl cellulose $1 \%$ and $2 \%$ is homogeneous. The pH test results showed that the gel preparation did not change $p H$. Dispersing test showed concentration hydroxyethyl cellulose $1 \%$ has the highest dispersion value. but statistical paired $T$ test results showed that the dispersion before and after storage was accelerated significantly different 0.043 ( $p<0.05$ ), but still in accordance with the range of dispersion specifications for a good semisolid preparation.The Minium Inhibitory Concentration test results showed formulation F1, F2 and F3 ethanol extract red onion skin gel are strong inhibitory effect, ethanol extract of red onion skin gel F1 inhibitory zone is 16mm, F2 and F3 had the same inhibitory zone is 14.33. It can be concluded F2 has the best physical stability, but F1 is the most effective to inhibit Staphylococcus aureus.
\end{abstract}

Keywords : Red Onion Skin, Hydroxy Ethyl Cellulose, Physical Stability, Gel

\section{PENDAHULUAN}

Saat ini, masyarakat umumnya menggunakan sediaan gel hand sanitizer sebagai jalan keluar untuk menjaga kesehatan dan kebersihan tangan karena lebih praktis dan mudah dibawa (Shu,2013). Hand sanitizer merupakan sediaan yang mampu membunuh mikroba baik dalam bentuk, cairan, gel atau sabun. Alkohol efektif terhadap sebagian besar bakteri, jamur, dan virus, dengan mekanisme kerja membunuh organisme ini dengan mendenaturasi protein atau lapisan membran lipid dari mikroba sehingga terjadi lisis. Namun, alkohol dapat menyebabkan kekeringan dan iritasi pada kulit. Hal ini mendasari pengembangan bahan antimikroba non alkohol.

Salah satu umbi yang melimpah di Indonesia adalah Allium sp (spesies bawang) dan secara tradisional 
digunakan untuk mengendalikan infeksi jamur. Bawang merah (Allium cepa L.) kaya akan dua kelompok phytochemical (Flavonoid dan alkenyl sulphoxidessistein) yang bermanfaat bagi kesehatan manusia. Enam belas flavonol yang berbeda telah diidentifikasi dalam bawang yang terdiri dari aglikon dan turunannya glikosilasi dari quercetin, isorhamnetin dan kaempferol (Hanninen et al., 2000).

Dari beberapa penelitian yang telah dilakukan ditemukan bahwa bawang merah (Allium cepa.L) secara in vitro memiliki aktivitas terhadap beberapa mikroba. Jika dalam keadaan kering tanpa dikupas umbi bawang merah dapat disimpan lama, hal ini memperlihatkan bahwa kulit bawang merah mempunyai senyawa aktif yang dapat melindungi umbinya.

Menurut penelitian, ekstrak kulit bawang merah mempunyai daya hambat terhadap pertumbuhan bakteri, dimana konsentrasi ekstrak kulit bawang merah yang digunakan sebesar 5\% memiliki diameter zona hambat 7,00 $\mathrm{mm}$ (Misna dan Diana, 2016) sedangkan kontrol diameter zona hambat mulai $5 \mathrm{~mm}$ (Fitri, 2016). Kandungan senyawa yang dapat menghambat bakteri atau mikroba yaitu senyawa flavonoid (Ashar, 2016), dari penelitian tersebut ekstrak kulit bawang merah dapat dimanfaatkan sebagai gel hand sanitizer. Berdasarkan latar belakang diatas penelitian ini bertujuan membuat suatu sediaan gel hand sanitizer dari limbah kulit bawang merah (Allium cepa.L) yang efektif dan stabil.

\section{METODE PENELITIAN}

ALAT DAN BAHAN

Alat-alat yang digunakan dalam penelitian ini adalah: alat gelas, autoklave, inkubator, Laminar air flow (LAF), alat pembuatan dan pengujian gel hand sanitizer, alat pengujian aktivitas antimikroba, perangkat alat maserasi, rotavapor, timbangan analitik dan oven.

Bahan-bahan yang digunakan dalam penelitian ini aquadest, hidroksietil selulosa, DMDM hydantoin, ekstrak etanol kulit bawang merah, etanol $96 \%$, gliserin, kertas millimeter blok, medium nutrient agar, menthol, Staphylococcuc aureus dan TEA.

\section{PROSEDUR KERJA}

\section{Penyiapan Sampel Penelitian}

Kulit bawang merah disortasi basah, dicuci, ditiriskan dan dijemur dengan menggunakan penutup kain berwarna hitam kemudian dirajang dan dikeringkan. Simplisia kulit bawang merah yang telah kering ditimbang sebanyak 1000 gram dimaserasi dalam 21 liter etanol 96\% selama 3 hari dan diaduk sesekali. Hasil yang didapatkan disaring dan diuapkan dengan rotary evaporator sampai diperoleh ekstrak kental. 


\section{Formulasi Sediaan Gel Handsanitizer}

Tabel 1.Rancangan Formula sediaan gel hand sanitizer

\begin{tabular}{|c|c|c|c|c|c|}
\hline \multirow{3}{*}{ Nama Bahan } & \multirow{3}{*}{ Satuan } & \multicolumn{3}{|c|}{ Penimbangan } & \multirow{3}{*}{ Fungsi } \\
\hline & & & Bahar & & \\
\hline & & $\mathrm{F} 1$ & $\mathrm{~F} 2$ & F3 & \\
\hline $\begin{array}{l}\text { Ekstrak etanol } \\
\text { kulit bawang } \\
\text { merah }\end{array}$ & $\%$ & 5 & 5 & 5 & Bahan Aktif \\
\hline Etanol $96 \%$ & Ml & 10 & 10 & 10 & $\begin{array}{c}\text { Pelarut ekstrak } \\
\text { dan efek } \\
\text { Sinergis }\end{array}$ \\
\hline $\begin{array}{l}\text { Hidroksietil } \\
\text { selulosa }\end{array}$ & $\%$ & 0,5 & 1 & 2 & Basis gel \\
\hline Trietanolamin (TEA) & $\%$ & 2,5 & 2,5 & 2,5 & $\begin{array}{c}\text { Agen } \\
\text { Pengalkali }\end{array}$ \\
\hline $\begin{array}{l}\text { DMDM } \\
\text { hydantoin }\end{array}$ & $\%$ & 0,2 & 0,2 & 0,2 & Pengawet \\
\hline Gliserin & $\%$ & 5 & 5 & 5 & Humektan \\
\hline Mentol & $\%$ & 0,5 & 0,5 & 0,5 & Pewangi \\
\hline Aquadest & $\mathrm{mL}$ & $\begin{array}{l}\text { Ad } \\
100\end{array}$ & $\begin{array}{l}\text { Ad } \\
100\end{array}$ & $\begin{array}{l}\text { Ad } \\
100\end{array}$ & Pelarut \\
\hline
\end{tabular}

Pembuatan sediaan gel hand sanitizer

Beker gelas dan sendok tanduk disiapkan. Hidroksietil selulosa ditimbang sebanyak $0,5 \%, 1 \%, 2$ \%dan masing-masing ditaburkan diatas akuades $80 \mathrm{~mL}$ yang sudah dipanaskan. Hidroksietil selulosa yang sudah ditaburkan diaduk cepat di dalam beker gelas sampai terbentuk masa gel dan ditambahkan TEA sebanyak 2,5\%. DMDM hydantoin ditimbang sebanyak $0,2 \%$ dan dilarut dalam aquadest sebanyak $5 \%$, dimasukkan ke dalam beker gelas, diaduk sampai homogen. Gliserin dan mentol ditambahkan kedalam beker gelas, diaduk sampai homogen. Ekstrak kulit bawang merah ditimbang sebanyak $5 \%$ dan dilarutkan dengan etanol $96 \%$ sebanyak $10 \mathrm{ml}$ dan diaduk sampai larut. Ekstrak kulit bawang merah yang sudah larut dimasukkan ke dalam beker gelas, dicampur sampai homogen, dan digerus sampai terbentuk gel.

\section{Evaluasi Kestabilan Fisik Gel Handsanitizer}

Uji stabilitas penyimpanan dipercepat dilakukan pada sediaan gel hand sanitizer yaitu dengan menyimpan gel hand sanitizer pada suhu dingin $10^{\circ} \mathrm{C}$ selama 24 jam, lalu dikeluarkan dan disimpan pada suhu $25-29^{\circ} \mathrm{C}$ selama 24 jam disebut 1 siklus. Pengerjaan ini dilakukan sebanyak 3 siklus yaitu selama 6 hari dengan pengamatan setiap siklus (2 hari). Pada akhir siklus dilakukan pengujian sifat fisik berupa 
pengamatan organoleptis, homogenitas, pengukuran daya sebar dan $\mathrm{pH}$ sediaan

\section{a. Uji organoleptik}

Uji organoleptis dilakukan secara visual terhadap sediaan gel meliputi perubahan warna, aroma/bau dan tekstur, yang diamati menggunakan panca indera sebelum dan setelah penyimpanan dipercepat.

\section{b.Uji homogenitas}

Pemeriksaan homogenitas sediaan dapat dilakukan dengan cara, sediaan dioleskan pada dua keping kaca atau bahan transparan lain yang cocok, sediaan harus menunjukkan susunan yang homogen dan tidak terlihat adanya butiran kasar), dilakukan 3x replikasi dengan cara kerja yang sama sebelum dan setelah penyimpanan dipercepat.

\section{c. Uji daya sebar}

Gel 0,5 gram diletakkan di tengah cawan petri yang telah ditempeli dengan kertas millimeter blok. Penyebaran gel diukur setelah dibiarkan selama 1 menit. Pengukuran diameter gel dimulai tanpa beban, kemudian ditambahkan beban 50 gram sampai diperoleh daya sebar yang konstan dan dicatat diameter penyebaran gel setelah 1 menit, dilakukan $3 \mathrm{x}$ replikasi dengan cara kerja yang sama sebelum dan setelah penyimpanan dipercepat.

\section{d. Uji pH}

Sampel ditimbang sebanyak 1 gram., kemudian ditambahkan sebanyak 10 $\mathrm{mL}$ aquadest $\mathrm{pH} 7$, lalu dilakukan pengadukan. Setelah homogen dilakukan pengukuran $\mathrm{pH}$ dengan cara memasukan $\mathrm{pH}$ meter, didiamkan beberapa saat sehingga didapat $\mathrm{pH}$ yang tetap, dilakukan 3x replikasi dengan cara kerja yang sama sebelum dan setelah penyimpanan dipercepat.

\section{Uji aktivitas antimikroba dari sediaan Gel hand sanitizer}

a. Penyiapan Bakteri Uji (Staphylococcus aureus)

1. Peremajaan biakan murni bakteri uji

Dari kultur murni mikroba diambil satu ose dan diinokulasikan dengan cara digoreskan pada agar miring dari medium Nutrient agar kemudian diinkubasikan pada suhu $37^{\circ} \mathrm{C}$ selama 1 x 24 jam.

2. Pembuatan suspensi bakteri uji Dari hasil peremajaan bakteri Staphylococcus aureus diambil 1 (satu) ose kemudian disuspensikan dengan aquadest steril sebanyak $10 \mathrm{ml}$ ke dalam tabung reaksi steril.

\section{b. Pengujian Pengaruh Gel Ekstrak Etanol Kulit Bawang Merah}

Disiapkan medium Nutrien agar steril dengan suhu $45^{\circ}-47^{\circ} \mathrm{C}$ lalu dituang secara aseptis ke dalam cawan petri steril sebanyak $20 \mathrm{ml}$ dan dibiarkan memadat. Setelah itu, dibuat sumuran pada media agar yang telah dipadatkan menggunakan pencadang, diberi tanda pada masing-masing lubang sumuran dengan konsentrasi $0,5 \% \mathrm{~b} / \mathrm{v}, 1 \% \mathrm{~b} / \mathrm{v}$, $2 \% \mathrm{~b} / \mathrm{v}$ dan kloramfenikol $0,02 \% \mathrm{~b} / \mathrm{v}$ sebagai kontrol positif, diletakkan secara aseptis diatas permukaan medium yang telah diolesi bakteri dengan jarak lebih kurang sama dengan 
yang lainnya. Selanjutnya diinkubasi pada suhu $37^{\circ} \mathrm{C}$ selama 24 jam.

\section{c. Pengamatan dan Pengukuran Diameter Hambatan}

Pengamatan dan pengukuran diameter hambatan dilakukan setelah masa inkubasi 1x24 jam. Zona hambatan yang terbentuk diukur dengan menggunakan mistar atau jangka sorong dan dicatat pada tabel pengamatan.

\section{HASIL DAN PEMBAHASAN}

Banyaknya penyakit atau gangguan kesehatan, baik gangguan kesehatan ringan maupun berat yang disebabkan oleh mikroorganisme yang ada pada tangan, WHO (2005) merekomendasikan dua cara untuk menjaga kebersihan tangan yaitu mencuci tangan dan mengaplikasikan sediaan antiseptik. Sediaan hand sanitizer telah terbukti mengurangi infeksi bakteri pada saluran pencernaan di berbagai kalangan masyarakat (Reynolds et al., 2006). Gel hand sanitizer sebagai jalan keluar untuk menjaga kesehatan dan kebersihan tangan karena lebih praktis dan mudah dibawa.

Bawang merah (Allium cepa L. ) mengandung dua kelompok phytochemical (Flavonoid dan alkenyl sulphoxidessistein), Enam belas flavonol yang berbeda telah diidentifikasi dalam bawang yang terdiri dari aglikon dan turunannya glikosilasi dari quercetin, isorhamnetin dan kaempferol. Bawang merah mempunyai kandungan sulfur compound seperti Allyl Propyl Disulphida (APDS) dan flavonoid seperti quercetin yang dipercaya bisa mengurangi resiko kanker, penyakit jantung dan kencing manis. Kulit bagian luar bawang yang mengering dan kerap berwarna kecoklatan kaya serat dan flavonoid yang memiliki aktifitas antibakteria terhadap Staphylococcus aureus dan E. coli. Komponen kimia tersebut bertanggung jawab dalam aktivitas yang diberikan oleh bawang merah (Hanninen et al., 2000).

Menurut Lanzotti, 2012 komponen fungsional sebagai antimikroba adalah saponin dan AceAMP1. Peran saponin pada tanaman tidak sepenuhnya dijelaskan tapi ada bukti kuat bahwa saponin bertindak sebagai senyawa pertahanan terhadap serangan mikroba patogen . saponin spirostanol yang dikenal dengan agigenin 3-O-trisakarida dan gitogenin 3-O-tetrasaccharide telah terbukti memiliki aktivitas antimikroba (Sadeghi et al., 2013).

Ace-AMP1 adalah kelompok peptida yang berpotensi sebagai antimikroba yang ditemukan di bawang merah (Allium cepa. L). Yang memiliki sequence yang sama dengan protein lipid transfer pada tanaman. Tanaman yang memiliki overekspresi terhadap gen ace-AMP1 dapat meningkatkan resistensi terhadap bakteri patogen. Dalam penelitian lain, Ace-AMP1 menunjukkan aktifitas yang tinggi terhadap Escherichia coli ( Hanninen et al., 2000).

Setiap sediaan farmasi yang akan dikembangkan harus melewati tahap pengujian untuk melihat kestabilannya pada penggunaan ataupun penyimpanan jangka pajang. Pengujian 
kestabilan tersebut dapat berupa pengujian kestabilan secara fisika, kimia dan mikrobiologi. Pada penelitian ini dilakukan uji kestabilan fisika, dimana akan dilakukan formulasi basis gel menggunakan hiroksietil selulosa dengan konsentrasi berbeda yaitu $0,5 \%$, $1 \%$ dan $2 \%$ dengan penyimpanan dipercepat selama 6 hari (3 siklus). Sediaan gel disimpan pada suhu $-10^{\circ} \mathrm{C}$ selama 24 jam lalu dikeluarkan dan ditempatkan pada suhu $25-29^{\circ} \mathrm{C}$, proses ini dihitung 1 siklus. Tujuan dilakukannya peyimpanan dipercepat adalah untuk mempercepat proses peruraian dari bahan-bahan dan untuk mempersingkat waktu pengujian. Evaluasi kestabilan fisika sediaan gel ditetapkan melalui pengamatan sifat organoleptik, uji homogenitas, uji $\mathrm{pH}$ dan uji daya sebar.

$$
\text { Pengamatan organoleptik }
$$

meliputi perubahan warna, aroma/bau dan tekstur, yang diamati menggunakan panca indera. Sehingga dapat dikatakan sediaan gel hand sanitizer tidak mengalami perubahan dari segi warna,bau, tekstur dan konsistensi sebelum dan sesudah penyimpanan dipercepat. Pengujian homogenitas F1 dengan konsentrasi basis $0,5 \%$ ini tidak homogen, hal ini menunjukkan bahwa gel ini tidak stabil. Pada F2 dengan konsentrasi basis 1\% ini homogen dan pada F3 dengan konsentrasi basis $2 \%$ ini homogen, hal ini menunjukkan bahwa formula gel ini stabil. Sehingga dapat dikatakan tidak ada pengaruh penyimpanan dipercepat terhadap homogenitas dari sediaan gel hand sanitizer tersebut. Berdasarkan hasil pengujian $\mathrm{pH}$ menunjukkan bahwa sediaan gel hand sanitizer tidak mengalami perubahan $\mathrm{pH}$ baik sebelum dan sesudah penyimpanan dipercepat. F1 dengan konsentrasi basis 0,5\% mempunyai nilai $\mathrm{pH} 7, \mathrm{~F} 2$ dengan konsentrasi $1 \%$ memiliki $\mathrm{pH} 7$ dan pada F3 dengan konsentrasi $2 \%$ memiliki $\mathrm{pH}$ 7. Nilai $\mathrm{pH}$ pada ketiga sediaan masih stabil dan masuk rentang $\mathrm{pH}$ kulit yaitu 4-8 sehingga tidak mengiritasi kulit.

Pada pengujian daya sebar didapatkan nilai daya sebar yang berbeda antar formula, dimana F2 dengan konsentrasi basis hidroksietil selulosa $1 \%$ memiliki nilai daya sebar tertinggi dibandingkan dengan formula gel yang lain. Sedangkan F3 dengan konsentrasi basis hidroksietil selulosa $2 \%$ mempunyai nilai daya sebar terendah. Hasil statistik uji $\mathrm{T}$ berpasangan statistik menunjukkan bahwa daya sebar sebelum dan setelah penyimpanan dipercepat berbeda signifikan dengan nilai signifikansi $0.043 \quad(p<0.05)$, sehingga dapat dikatakan bahwa daya sebar sebelum dan setelah penyimpanan dipercepat tidak stabil, namun masih sesuai dengan rentang nilai spesifikasi daya sebar untuk sediaan semipadat yang baik, Daya sebar 5-7 $\mathrm{cm}$ atau 4-6,5 $\mathrm{cm}$ menunjukkan konsentrasi semisolid yang sangat nyaman dalam penggunaan.

Uji MIC dilakukakan dengan cara membandingkan nilai MIC dari F1, F2 dan F3 dengan kontrol positif. Kontrol positif yang dipakai adalah suspensi dari salep kloramfenikol $0,02 \%$. Uji ini bertujuan untuk melihat pengaruh konsentrasi basis terhadap aktifitas ekstrak kulit bawang merah 
(Allium cepa L.) terhadap Staphylococcus aureus. Hasil menunjukkan bahwa diameter zona hambat terbentuk dimulai pada F1 adalah $16 \mathrm{~mm}$, kemudian pada $\mathrm{F} 2$ sebesar 14,33mm, F3 sebesar 14,33mm sedangkan perlakuan kontrol positif dengan menggunakan cara sumuran yang berisi salep kloramfenikol, zona hambat yang terbentuk sebesar 33,67 $\mathrm{mm}$. Semakin tinggi konsentrasi pada basis yang digunakan maka viskositas sediaan gel akan semakin kental sehingga absorpsi dari gel untuk menghambat bakteri Staphylococcus aureus akan menjadi menurun yang berakibat pada penurunan diameter zona hambat bakteri.

Pada perlakuan kontrol positif dengan menggunakan kloromfenikol, dalam hal ini kloramfenikol memperlihatkan rata-rata zona hambat yang lebih besar dibandingkan dengan sampel uji. Namun berdasarkan hasil uji diameter daya hambat semua formulasi yang dibuat memiliki aktivitas terhadap bakteri Staphylococcus aureus. Daya hambat dibagi atas : sangat kuat (zona jernih > $20 \mathrm{~mm}$ ), kuat (zona jernih 10$20 \mathrm{~mm}$ ), sedang (zona jernih 5-10 mm) dan lemah (zona jernih $<5 \mathrm{~mm}$ ). Kontrol positif tergolong dalam sediaan yang memberikan daya hambat sangat kuat yaitu 33,67 mm. Gel ekstrak etanol kulit bawang merah F1, F2 dan F3 termasuk dalam sediaan yang memberikan daya hambat kuat yaitu gel ekstrak etanol kulit bawang merah F1 daya hambat sebesar 16mm, F2 dan F3 memilki daya hambat yang sama sebesar 14,33.
Berdasarkan hasil uji post hoc tukey menunjukkan bahwa Formulasi ekstrak etanol kulit bawang merah memiliki aktivitas terhadap bakteri Staphylococcus aureus yang lebih baik dibandingkan dengan aktivitas ekstrak etanol kulit bawang merah yang tidak diformulasi dimana nilai signifikansi terhadap kontrol negatif (ekstrak etanol kulit bawang merah) masing-masing formulasi yaitu $F 1=0.002, \quad F 2=0,010$ dan $\quad F 3=0.010 \quad(p<0.05), \quad$ namun aktivitasnya tidak lebih baik dibandingkan dengan kontrol positif (kloramfenikol).

\section{SIMPULAN}

Berdasarkan hasil penelitian yang telah dilakukan maka dapat disimpulkan bahwa F2 (hidroksi etil selulosa $1 \%$ ) memiliki stabilitas fisik yang yang terbaik, namun formulasi $\mathrm{F} 1$ (hidroksi etil selulosa 0,5\%) paling efektif menghambat bakteri Staphylococcus aureus.

\section{UCAPAN TERIMAKASIH}

Pada kesempatan ini, peneliti ingin mengucapkan terima kasih kepada berbagai pihak yang telah membantu terwujudnya penelitian ini :
1. Yayasan STIKES Nani Hasanuddin Makassar
2. Pusat Penelitian dan Pengabdian Kepada Masyarakat STIKES Nani Hasanuddin Makassar
3. Program Studi D3 Farmasi STIKES Nani Hasanuddin Makassar


DAFTAR PUSTAKA

Ashar, M. (2016). Formulasi dan Uji Stabilitas Fisik Sediaan Gel Ekstrak Daun Botto'-Botto' (Chromolaena Odorata) Sebagai Obat Jerawat dengan Menggunakan Variasi Konsentrasi Basis Karbopol (Doctoral dissertation, Universitas Islam Negeri Alauddin Makassar).

Dirjen POM. 1995. Farmakope Indonesia, edisi IV, Departemen Kesehatan Republik Indonesia, Jakarta.

Fitri, L. (2010). Kemampuan daya hambat beberapa macam sabun Antiseptik terhadap pertumbuhan Staphylococcus aureus dan Escherichia coli. Jurnal Biologi Edukasi, 2(2), 33-39.

Hanninen, O., Kaartinen, K., Rauma, A. L., Nenonen, M., Törrönen, R., Häkkinen, S., ... \& Laakso, J. (2000). Antioxidants in vegan diet and rheumatic disorders. Toxicology, 155(1-3), 45-53.

Lanzotti, V., Barile, E., Antignani, V., Bonanomi, G., \& Scala, F. (2012). Antifungal saponins from bulbs of garlic, Allium sativum L. var. Voghiera. Phytochemistry, 78, 126-134.

Misna, M., \& Diana, K. (2016). Aktivitas antibakteri ekstrak kulit bawang merah (Allium cepa 1.) terhadap bakteri Staphylococcus aureus. Jurnal Farmasi Galenika (Galenika Journal of Pharmacy), 2(2), 138-144.

Reynolds, S.A., Levy, F., Walker, E.S.,, Anti acne Alert. (2006). Emerging Infectious Diseases. 12(3), 527529.

Sadeghi, M., Zolfaghari, B., Senatore, M., \& Lanzotti, V. (2013). Spirostane, furostane and cholestane saponins from Persian leek with antifungal activity. Food chemistry, 141(2), 1512-1521.

Shu, M. (2013). Formulasi sediaan gel hand Sanitizer dengan bahan aktif Triklosan $0, \quad 5 \%$ dan 1\%. Calyptra, 2(1), 1-14.

Wu, Y., He, Y., \& Ge, X. (2011). Functional characterization of the recombinant antimicrobial peptide Trx-Ace-AMP1 and its application on the control of tomato early blight disease. Applied microbiology and biotechnology, 90(4), 1303-1310.

World Health Organization. (2005). Guidelines for Hand Hygiene in Health-Care, Global Patient Safety Challenge, USA, 12-23. 